\title{
Paul Scarron, Théâtre complet
}

\section{Monica Pavesio}

\section{CpenEdition \\ Journals}

\section{Edizione digitale}

URL: http://journals.openedition.org/studifrancesi/6609

DOI: $10.4000 /$ studifrancesi.6609

ISSN: 2427-5856

\section{Editore}

Rosenberg \& Sellier

\section{Edizione cartacea}

Data di pubblicazione: 1 septembre 2010

Paginazione: 357-358

ISSN: 0039-2944

\section{Notizia bibliografica digitale}

Monica Pavesio, «Paul Scarron, Théâtre complet», Studi Francesi [Online], 161 (LIV | II) | 2010, online dal 30 novembre 2015, consultato il 09 janvier 2021. URL: http://journals.openedition.org/studifrancesi/ 6609 ; DOI: https://doi.org/10.4000/studifrancesi.6609

Questo documento è stato generato automaticamente il 9 janvier 2021.

\section{(c) (†)}

Studi Francesi è distribuita con Licenza Creative Commons Attribuzione - Non commerciale - Non opere derivate 4.0 Internazionale. 


\title{
Paul Scarron, Théâtre complet
}

\author{
Monica Pavesio
}

\section{NOTIZIA}

PAUL SCARRON, Théâtre complet, 2 volumes, Édition établie et présentée par Véronique STERNBERG, Paris, Champion, 2009, pp. 1256.

1 Più conosciuto come l'autore del Roman comique, Scarron fu anche uno dei migliori drammaturghi del suo tempo. Faceva parte di quel gruppo di autori che in perfetta sincronia adattarono nel ventennio compreso fra il 1640 ed il 1660 le comedias spagnole ai gusti del pubblico francese. Grazie alle sue commedie, fra le quali spiccano Jodelet ou le maître valet, Dom Japhet d'Armenie, l'Heritier ridicule, iniziò il rinnovamento del genere comico, che verrà portato avanti da Molière.

2 Situato cronologicamente fra Corneille e Molière, il teatro di Scarron - e degli altri drammaturghi che insieme a lui lavorarono in quegli anni al rinnovamento del genere comico - è una tappa importante dell'evoluzione della commedia del xvII secolo. Accogliamo quindi con entusiasmo l'edizione critica del teatro completo del drammaturgo curata da Véronique Sternberg, per le edizioni Champion.

La curatrice presenta le caratteristiche peculiari del teatro di Scarron ed i suoi legami con il mondo letterario dell'epoca. Si sofferma poi sul burlesco, sul concetto di imitazione e su quelle caratteristiche che rendono originale il teatro del drammaturgo. I testi vengono presentati con ortografia modernizzata, seguendo l'ultima edizione corretta dall'autore e la prima edizione per le opere pubblicate postume. Le varianti presenti nelle altre edizioni sono riportate in nota. Tutte le opere sono precedute da una breve presentazione che si sofferma sui rapporti con la fonte, sulla messa in scena e sulla ricezione della pièce. L'autrice aggiunge anche alcuni frammenti, bozze preparatorie di alcune delle sue commedie, che servono a mettere in luce il lavoro del drammaturgo.

4 Un annesso grammaticale molto curato, un glossario esaustivo ed una ricca bibliografia arricchiscono i due volumi. Constatiamo purtroppo che la studiosa francese, pur 
riportando nella ricca bibliografia tutte le edizioni moderne delle singole pièces di Scarron, non cita l'edizione critica del teatro completo del drammaturgo curata dalla collega italiana Barbara Sommovigo ed uscita per le edizioni Felici nel 2007 (vedi la segnalazione di C. Rolla su «Studi francesi» 158, p. 390). Immaginiamo a causa della scarsa diffusione del volume stampato in Italia, che rimane comunque la prima edizione critica moderna del teatro di Scarron. 